\title{
The temperate to arid transition of the Irwin - Carnarvon phytogeographic boundary, Western Australia
}

\author{
Neil Gibson, Allan H. Burbidge, G.J. Keighery and M.N. Lyons \\ Department of Conservation and Land Management, PO Box 51, Wanneroo, \\ Western Australia 6065, Australia
}

\begin{abstract}
The southern boundary of the Carnarvon phytogeographic district separates the arid Acacia shrublands from the species rich heaths and woodlands of the Irwin region. This boundary has previously been mapped at a scale of 1:250000 using the structure, density and composition of the dominant perennial plant species. One hundred quadrats were established across this boundary to determine if floristic composition correlated with the mapped position of this boundary. Our results suggest that the boundary of the Southwestern Botanical Province should move west and south to exclude the Acacia - Casuarina thicket on red sandplain and the tree heaths south of Shark Bay. In terms of species and family composition the vegetation of these areas is more similar to typical Carnarvon vegetation than to the scrub heaths of the yellow sandplains of the Irwin. Major edaphic patterns are strongly correlated with the position of the revised boundary.
\end{abstract}

\section{INTRODUCTION}

The boundary between the Southwestern and Eremaean Botanical Provinces runs roughly southeast from Shark Bay (Beard, 1976a) and bisects the lower third of the Carnarvon Basin study area of Keighery et al. (2000; Figure 1). This boundary represents the transition from the complex and species rich heathlands and woodlands of southwestern Australia to the less diverse Acacia shrublands of the Carnarvon Basin and is clearly related to the increasing quantity and reliability of rainfall to the south-west (Beard, 1976a). This major floristic boundary was first mapped by Diels (1906) and later work by Gardner (1944) and Gardner and Bennetts (1956) further refined its position but on maps at very large scale. Detailed mapping of this boundary did not take place until Beard's pioneering Vegetation of Western Australia project was undertaken, culminating in the publication of vegetation maps of the south-west at $1: 250000$ scale and the rest of the State at 1:1000000 scale (e.g. Beard, 1975, 1976a, 1976b, 1976c) and allowing detailed boundaries for 21 districts and 4 subdistricts to be defined across the State (Beard, 1980). The terminology of these districts has subsequently undergone some minor modification (Beard, 1990).

Beard's vegetation mapping used vegetation structure, density and composition and generally showed remarkable concordance with the earlier published phytogeographic boundaries (Beard, 1976b). The position of this boundary in the Shark Bay area is, however, equivocal due to the intermediate nature of the structure and floristic variation in the vegetation. Diels (1906) originally included Edel Land and Peron Peninsula in the Southwestern Province, Gardner (1944) and Gardner and Bennetts (1956) showed the boundary bisecting the Peron Peninsula, while Burbidge (1960) followed Diels' line. Beard (1976b) considered that Peron Peninsula with its Acacia ramulosa scrub and Triodia plurinervata hummock grasslands clearly represented southern Eremaean vegetation, as did the vegetation of Bernier and Dorre Islands. The tree heaths of the Tamala area (immediately south of Shark Bay) are a unique vegetation type. Beard (1976a, 1976b) considered these tree heaths had clear floristic affinities to the Acacia - Casuarina thicket of the Eurardy system (within the Irwin botanical district).

Edel Land and Dirk Hartog Island, however, have a complex of intermediate vegetation types with affinities both to the Eremaean and the Southwestern Provinces (Beard, 1976b). Beard placed Edel Land and Dirk Hartog Island in the Eremaean Province based on general impression of desolation and aridity while recognising their intermediate character. In subsequent work on Dirk Hartog Island Burbidge and George (1978) disagreed with the placement of this island in the Eremaean Province and considered it better treated as a 'transitional zone' or placed in the Southwestern Province based on its flora and vegetation formations with the exception of the hummock grassland. In the most recent review of the biogeographic regions in Western Australia, Thackway and Cresswell (1995) placed Edel Land in the Southwestern Province (in their Geraldton 


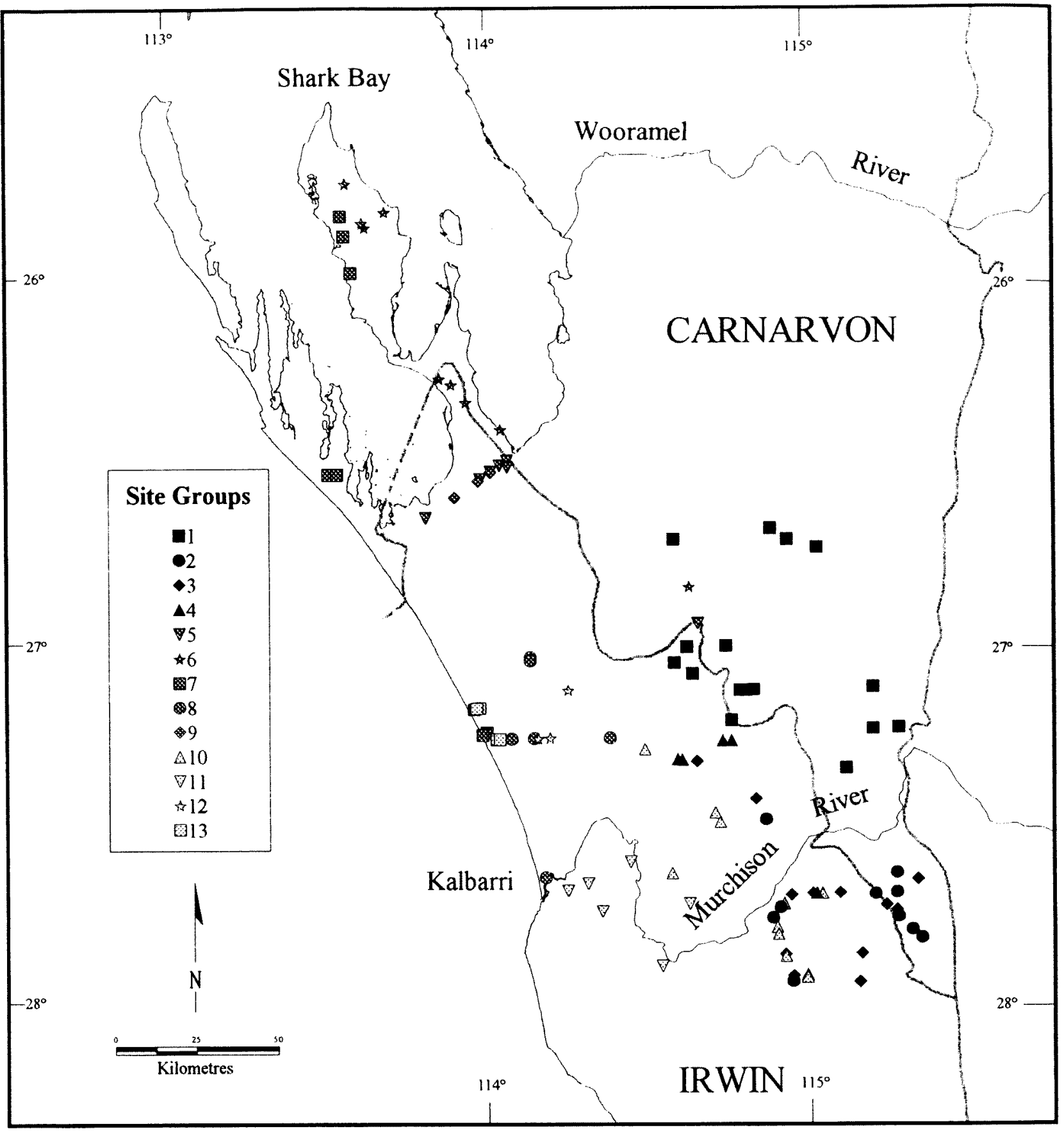

Figure 1 Location of sites in the study area showing site groupings based on floristic similarity. Boundaries between phytogeographic districts (Beard, 1980) shown as solid lines.

Sandplains Region) and Dirk Hartog Island with Peron Peninsula in the Eremaean Province.

Beard (1976a, 1976b, 1976c) has also mapped vegetation systems within the districts of the Southwestern Province and for part of the Carnarvon botanical district. Vegetation systems consist of particular series of plant communities recurring in catenary sequences or mosaics linked to topographical, pedological and/or geological features (Beard, 1976a, 1976b, 1976c). The aim of the present paper is to test the placement of the Carnarvon - Irwin boundary and the vegetation system boundaries within these two districts using plot-based floristic data derived from 100 quadrats straddling the Irwin - Carnarvon boundary.

\section{METHODS}

One hundred sites occurring on sandplains were sampled across the Irwin - Carnarvon boundary from Peron Peninsula to south of the Murchison River (Figure 1) where access permitted. Quadrats $30 \mathrm{~m} \times 30 \mathrm{~m}$ were established at each site and all vascular plant species occurring in the quadrats were recorded. Recently burnt sites were avoided. Seventy-five quadrats were established on four 
spring sampling trips during 1988-92, following good winter rains. Most of these quadrats were sampled once. A further 25 quadrats were established in August 1994, with most being revisited in August 1995. As all sites were visited at least once following good winter rains, differences in species composition in the dataset due to seasonality were considered to be minimal. Each site was allocated to the appropriate phytogeographic district and vegetation system following Beard (1980, 1976b, 1976c).

Sites were classified according to similarities in species composition (presence/absence data) using the Czekanowski coefficient and 'unweighted pairgroup mean average' fusion method (UPGMA, Sneath and Sokal, 1973), while species were classified using the 'two step' method of Austin and Belbin (1982) and the UPGMA fusion method. Annuals and geophytes were included in the analysis as all sites were considered to have had good rains prior to the sampling period.

A bulked soil sample of the top $10 \mathrm{~cm}$ was collected from 96 of the 100 sites and soil mechanical analysis and macro nutrient analyses were undertaken on these samples using standard techniques (McArthur, 1991). Climate parameters for each site were estimated from the climate modelling program AUSCLIM [see Wyrwoll et al. (2000) for details]. Statistical relationships between site groups (at the 13 group level) and within the three major groups identified were tested using Kruskal-Wallis non-parametric analysis of variance (Siegel, 1956).

Nomenclature generally follows Green (1985) and current usage at the Western Australian Herbarium. Selected voucher specimens have been lodged in the Western Australian Herbarium.

\section{RESULTS}

\section{Vegetation classification}

Six hundred and ninety taxa (species, subspecies and varieties) were recorded from the 100 quadrats. Of these, $224(32 \%)$ were recorded at only one site. Preliminary analyses showed these singletons contained little information and were subsequently excluded from the analysis. The 466 remaining taxa were recorded from between two and 48 sites. Species richness ranged between 10 and 73 taxa/ plot. The classification is discussed at two levels, the 3 group level (referred to as groups I, II and III) and the 13 group level (referred to as site group 1 to site group 13) (Figure 2).

At the three group level the 100 sites fall in more or less discrete geographical entities, with group I occupying the southern inland sector, group II the northern coastal sector and group III the southern coastal sector (Figure 1). There is some degree of overlap in species composition between groups. Species assemblages $S, T, U$ and $V$ are characteristic of the southern coastal group with species assemblages $P, Q$ and $R$ being typical of the northern coastal group (Table 1). Species assemblage $O$ is well represented in both the northern coastal group and the southern inland group but largely lacking from the southern coastal group (Table 1). The northern coastal group occurs mostly on red sands, the southern inland groups occurs on either red or yellow sands and the southern coastal group was restricted to yellow sands.

These three major groups can be further divided into 13 site groups and the inverse analysis of the species gave 22 species assemblages (Table 1 ). The southern inland group (group I) can be subdivided into four site groups. All four site-groups are generally open mallee over Acacia shrublands often with emergent Callitris glaucophylla in site groups 1 , 2 and 3 . Site group 1 is largely restricted to the Toolonga plateau while site group 2 is found on the sandplain south of the Murchison River. Both groups have high representation of species assemblage $O$ but differ in terms of species assemblages A, B, L, M and N. Site group 1 had an average species richness of 38.6 taxa/site while site group 2 was richer with an average richness of 49.7 taxa/plot. Site group 3 differs from the previous two in having a diverse heath understorey (species assemblage $\mathrm{C}$ ), a much lower representation of species assemblage $O$, and lower overall species richness (average of 29.7 taxa/plot). Site group 4 was closely related to site group 3 but was less rich (average 20.4 taxa/plot) and had low to moderate representation of species assemblages $G, H$ and I which are more typical of the northern coastal group (group II).

The northern coastal group can be divided into 5 site groups. Site groups 5 and 9 largely correspond to the tree heath found on the red sands south of Shark Bay. This group also included an Acacia shrubland immediately adjacent to the boundary with the tree heath and an outlying site well to the south. This outlying site (48) would probably be better considered a species poor example of site group 1 (see Table 1). Site group 9 has lower average species richness (30.7 taxa/plot) than site group 5 (39.7 taxa/plot) and lower representation of species in species assemblages $\mathrm{O}$ and $\mathrm{P}$, with the missing taxa mostly being annuals or geophytes. Most sites in site group 5 were scored in 1991 while sites in site group 9 were scored in 1994 and 1995. These two site groups may represent a seasonal component in the dataset but no other floristic groupings were correlated with year of sampling.

Site group 6 includes Acacia shrublands on red sands on the Peron Peninsula with one outlying site to the south. Species richness averages 40.7 taxa/ 
Table 1 Two-way table showing three group classification, the 13 site groups and 22 species assemblages for 100 sites across the Carnarvon-Irwin boundary. Quadrats are shown as columns and taxa as rows. (Ms indicates manuscript name).

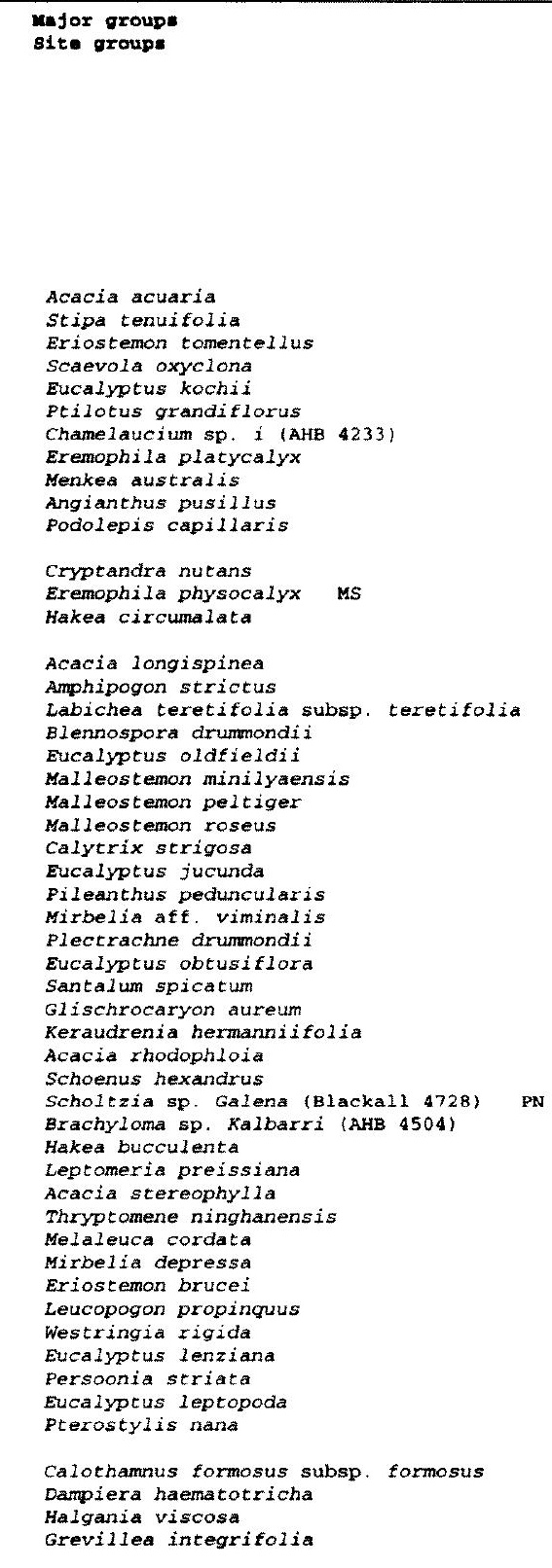

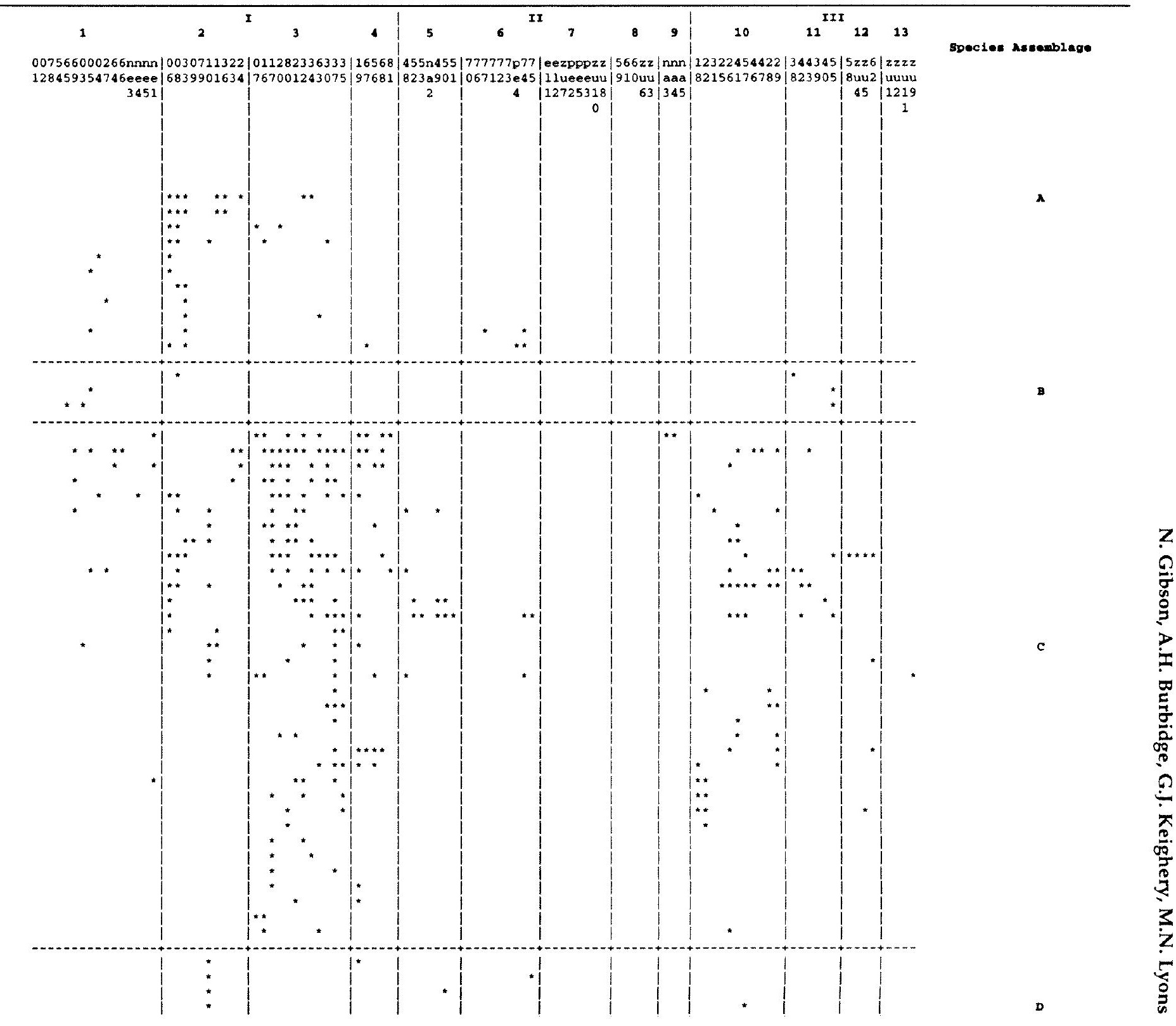


Eucalyptus transcontinentalis

Malreana george 2

Sisymbrium erysimcides

Acanthocarpus aff, robustus (Hopper 1367)

Thryptomene baeckeaced

plectrachne bromoides

Trachymene elachocarp

Acacia rostellifera

Stylobasium spathulat

Thysanotus paterson in

Melaleuca aff. nesophila (Beard 6768)

Acacia cochlearis

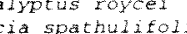

Calothannus borealis

Lechenaultia thationdes

Banksia ashby

Banksia sceptrum

Pityrodia atriplicina

(GJK and NG 1708) Persoonia acicularis
plectractine danthonioides

Acacia bivenosa

Trevillea stenobotrya

Baeckea sp. Nanga lGeorge 11346

Calandrinia disperm

Solanum hesperium

stipa compressa

Calandrinia liniflora

Calortothatella ceucrisflora

Jacksonia sp Boulder Hill GW

Acacia neurophylla

Melaleuca sp.

Murchisonia volubilis
pilearthus verrucostum

Acacia latipes

Eremophila occidens MS

Wurmbea cernua

Tricorgme aft corynothecoides (GJK and NG 1274 )

Malleostemon pedunculatus

Pityrodia glutinosa

Thryptomere sp. Tamala (ME Trudgen 7384

Anthocercis intricata

Rulingia molvifolia var boredis

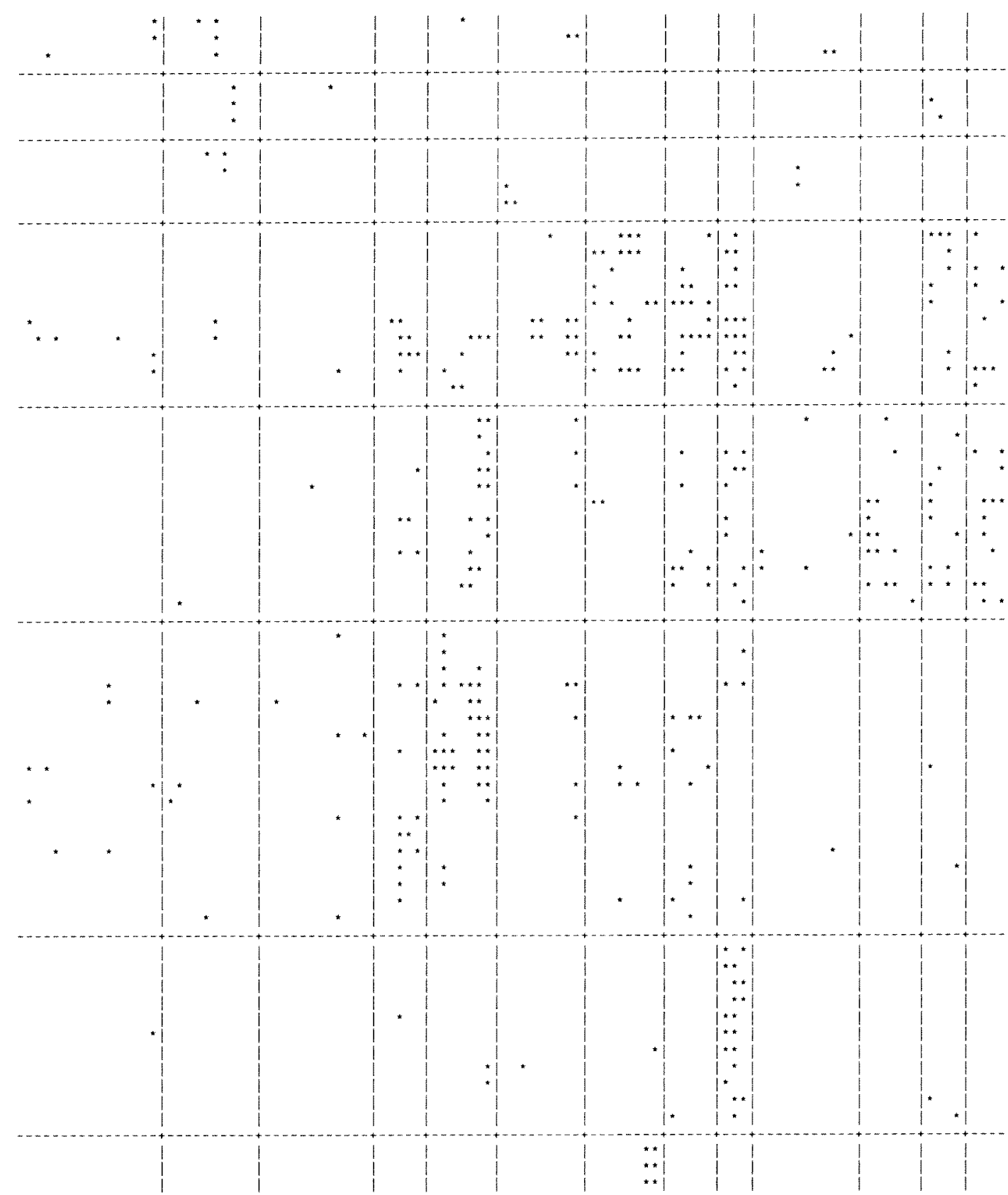




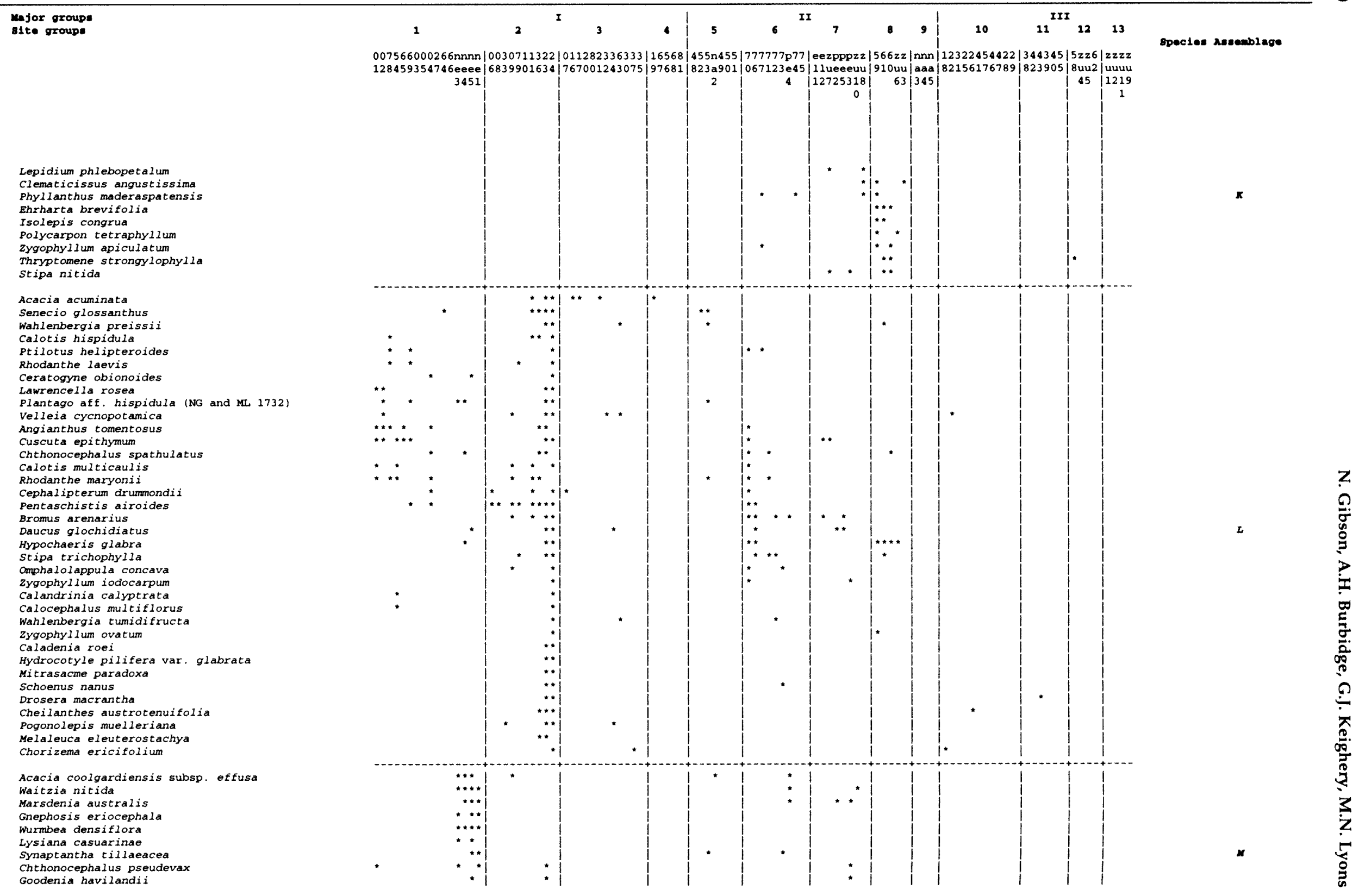


Erachychiton gregori

Thryptomene decussata

khodanthe stricta

Shodart he humboldt iand

stipa tucker.

Grevillea brachystachya

Grevdanthu bitinosum subsp glutinosum

Rhodarthe manglesii

Stenopetalum lineare

pityrodia paniculata

Acacia linophylla

Rhodarthe citrina

Brachyscome cheilocarpa

Calandrinia lehmannis

Lawrencella daverport is
Rhyncharrhena linear is

Rhyncharrhena inearis
ptilotus polystachyus

Tetragonia diptera

Brachyscome iberidifolia

Goodenia berardiana

Nicotiana occidentalis

Calandrinia polyandra

Pimelea microcephala

Ptilotus obovatus

Solanum orbiculatum

Crassula colorata

Erodium cygnorum

Prodium cygnorum

Millotia myosotidifolia

Acacia ramulosa

Goodenia occidentalis

Actinobole uliginosum

Grachyscome cillaris

Velieia glabrata

Brunonia australis

Eremophila clarke

Monachather paradoxus

Callitris glaucophylla

Bursaria occidentalis

Eucalyptus mannensis

Eremophila granitica

Eremophila latrobei

Lobelia gibbosa

Stenopetalum 1 infor

Persoonia bowgada

Allocasuarina acutivalvis

Bellida graminea

Comesperma integerrimum

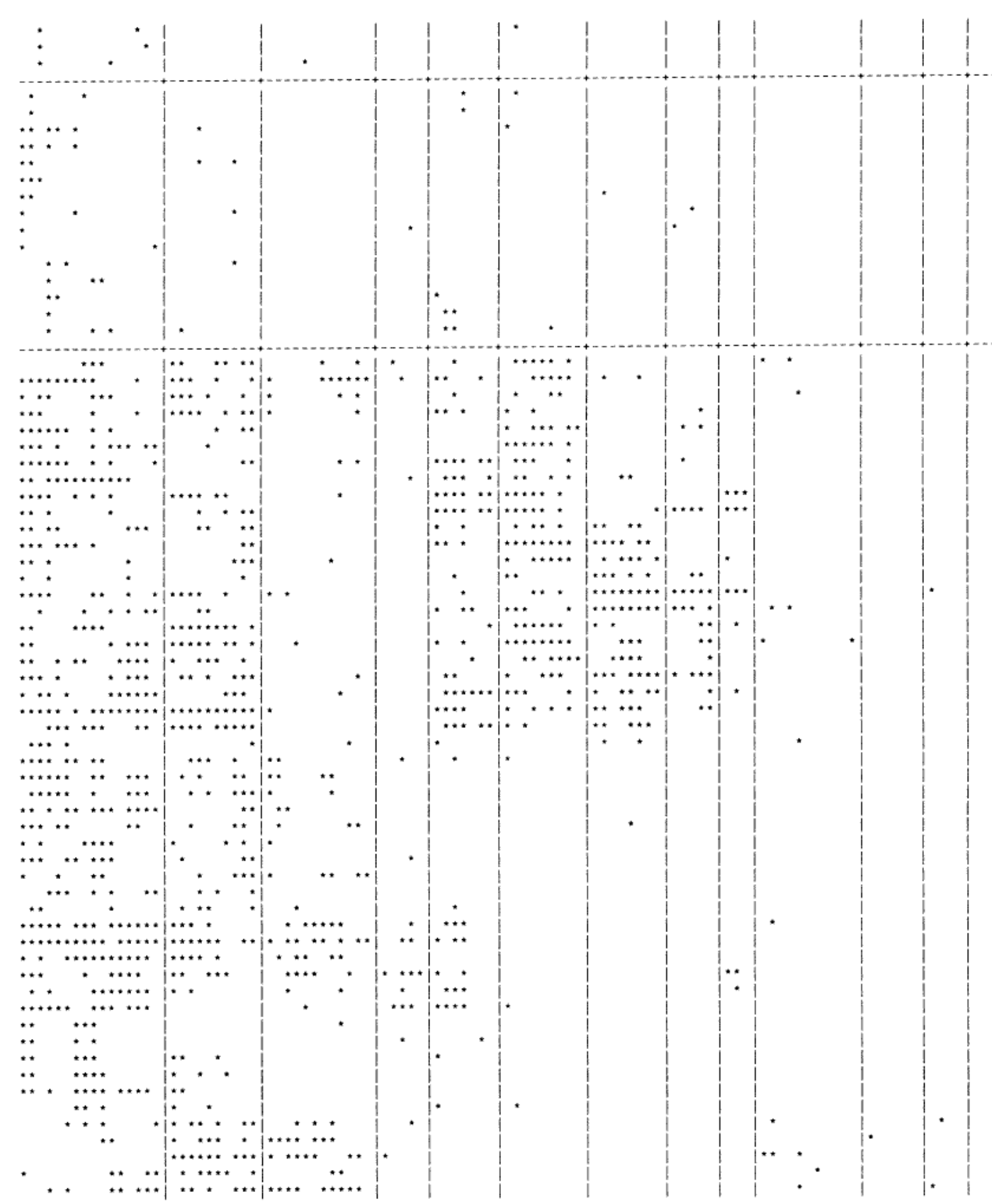


Major group

Uldinia ceratocarpa

Alyxia buxifolia
Cassia nemophila

Chthonocephalus muellerianus

Calandrinia corrigioloides

Gnephosis tenuissin

stipa elego

Thysanotus manglesianus

Eucalyptus eudesmioides

Lamarchea hakelfolla var. brevifolia

Poranthera microphylla

Olearia axillaris

Trachymene pilosa

Acacia ligulata

Melaleuca cardiophylla

paractaenum novae-hollandiae

Scaevola spinescens

Drocarpos aphy1lus

Threlkeldia diffusa

Sonchus oleraceus

zygophyllum fruts

Rhagodia preissis

Solanum lasiophyllum

Acacia tetragonophy1la

Brasicaphalus tomentellus

Ptilotus divaricatus

Enchylaena tomentosa

Rostraria pumila

Calocephalus francisi

Aristida holathera

Lobelia heterophylla

Heterodendrum oleifolium

Cassia chatelainiana

Cassia glutinosa

Atriplex vesicaria

Rhagodia drummondi

Eremophila glabra

Podotheca angustifolia

Acacia sclerosperma

Convolvulus erubescens

Euphorbia tannensis

olearia rudis

1

2 I 3

- 5

II

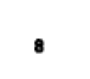

10

$11^{\text {II }}$

$12 \quad 13$

Species Nescabbiege

$007566000266 \mathrm{nnnn}|0030711322| 011282336333|16568| 455 \mathrm{n} 455|777777 \mathrm{p} 77|$ eezpppzz|566zz|nnn $|12322454422| 3443455|5 z z 6| 282$

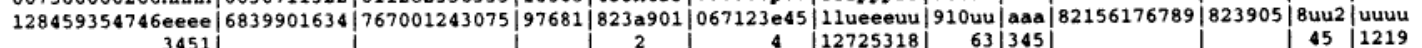


Brachyscome latisquanea

Trichanthodim skifrophorum

Erodium cicutarium

Eragrost is barrelier.

Lepidium rotundum

Gurmbea intramediana

Triodia piurinervata

Salsola kal

sclerolaena diacantha

Eragrostis diels

Urospermum picroides

Centaurea melitensis

Cassytha glabelia

Dysphania rhadinostachya

Frankeria pauciflora

Lepidium puberuium

stipa crinita

Lepidium linifolium

Tryptoments sp. Carrarang (Trudgen 7420 )

2ygophylium ammophilum
Diplolaena grandiflora

Thryptomene denticulata

Burnettia nigricans $\mathrm{M}$

Conostephium preissi

Hibbert is pungens

Conostylis stylidioides
Centrolepis drummondiand

Acacis cavealis ms

prosera stolonitera subsp. stolonifer

Hibbertia subvaginata

conospermum microfiorum

petrophile brevifolia

Schoenus clandestinus

Brachysema aphyllum
Melaieuca conothamnoides

Mysinema ciliatum

Scaevola canescens

Laxmannia sessilifiora

Cassytha aurea

Conipyon tundicans

Cassytha racemosa

byyandra borealis subsp. borealis

Hibbert ia spicata subsp. spicata

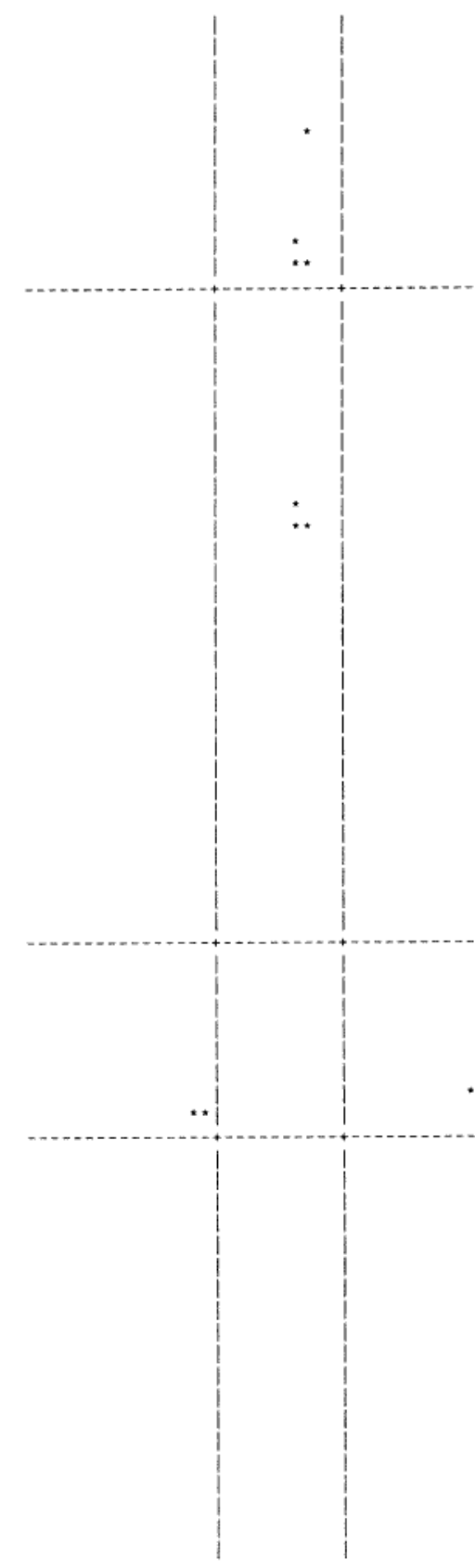




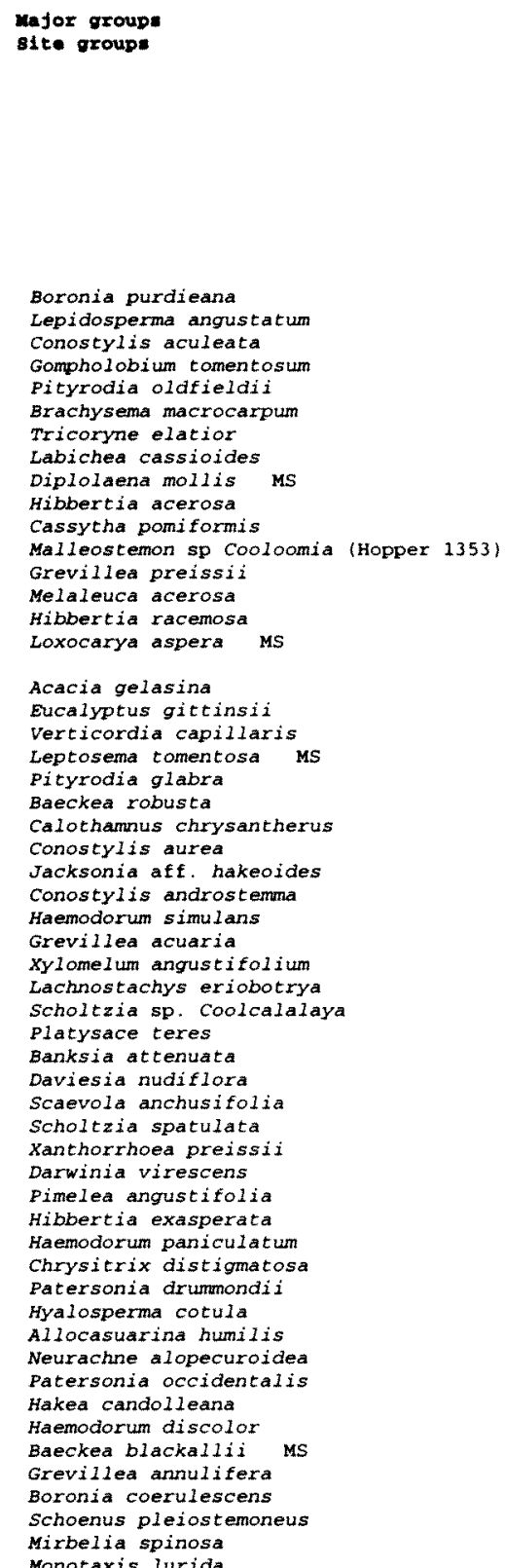

Boronia purdieana

epidosperma angustatum

Conostylis aculeata

pityrodia oldfieldi $i$

Brachysema macrocarpu

Tricoryne elatior

Diplolaena mollis MS

Hibbertia acerosa

Cassytha pomiformis

Heostenon sp Cooloomia (Hopper 1353 )

Grevillea preiss

Hibbertia racemosa
Loxocarya aspera

Acacia gelasina

Eucalyptus gittinsia

Verticordia capillaris
Leptosema tomentosa MS

Leptosema tomentos
Pityrodia glabra
Baeckea robusta

Calothamnus chrysantherus

Conostylis aure

Jacksonia aff. hakeoides

Haemodorum androstem

Grevillea acuaria

Xylomel um angustifolium

Scholtzia sp coobotrya

platysace teres

Banksia at tenuat

Daviesia nudiflora

Scaevola anchusifolia

Xanthorrhoea preissi

Darwinia virescens

Pimelea angustifolia

Haemodorum paniculatum

Chrysitrix distigmatosa

Patersonia drummondi

Hyalosperma cotula

Neurachne alopecuroidea

Patersonia occidentalis

Hakea candolleana

Baeckea blackallii

Grevillea annulifer

Boronia coerulescens

Schoenus pleiostemoneus

Mirbelia spinosa

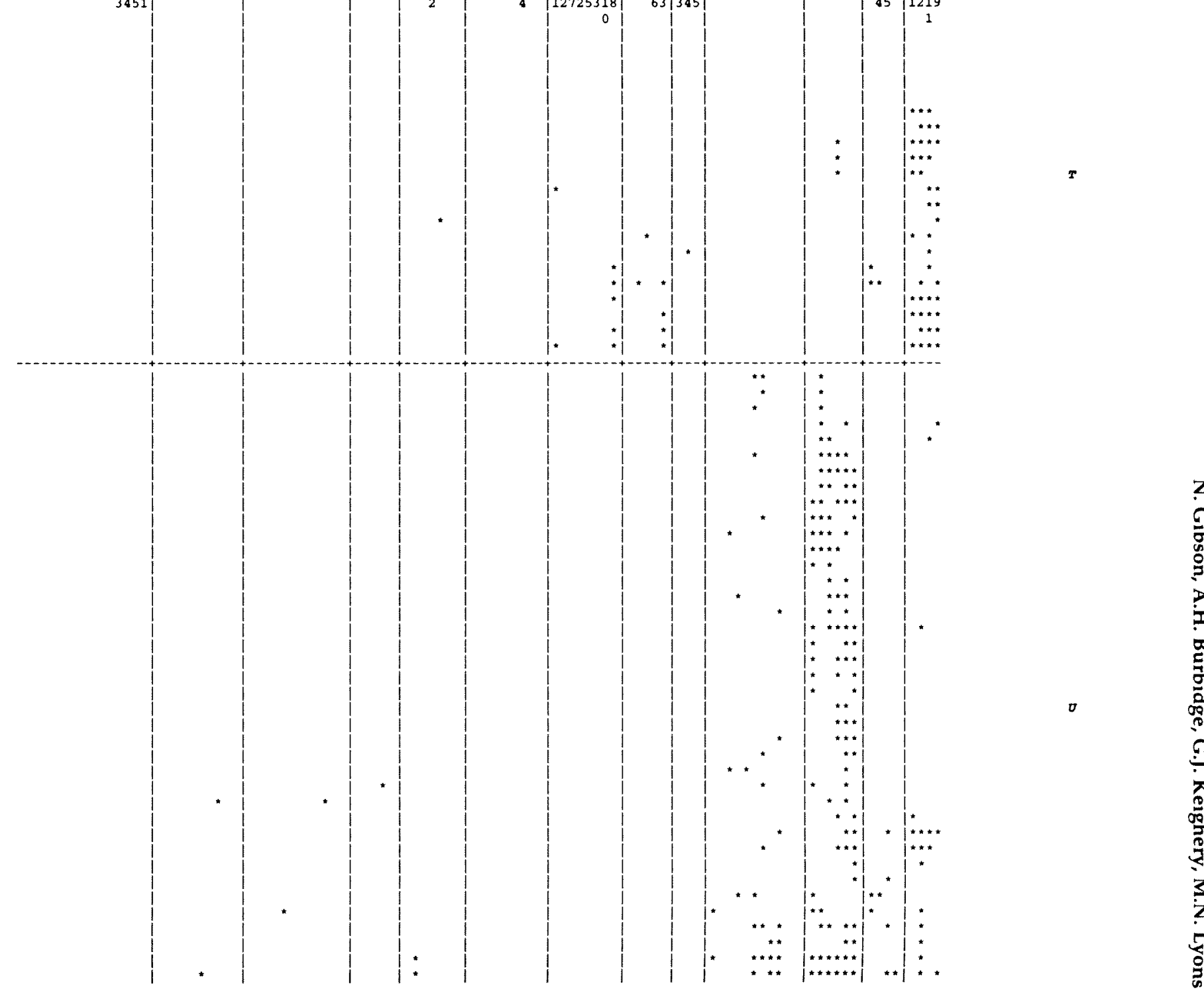


Acacia isoneura

Thysanotus specki

(Hopper 1428)

Lepidosperma terue

Dampiera oligophyl ta

Jacksonia nematoclada

comesperma scoparium

Thelymitra sargentis

Beaufortia squarrosa

Thryptomene sp. Wanda

Greviliea conmutat.

Acanthocarpus preissit

Calytize brevizolia

Hibbertia conspicua

Melaleuca scabra

Drosera menziesi i subsp. thysanosepald

Calothansus quadrifid

Geleznowia vertucosa

Grevillea erfortachya

opercularia aff spermacos

Actinostrobus arenarius

Grevillea candelabroides

Melaledca alf, holosertcea

Baeckea pent halactiansis

Flatysace commutata

Allocasuarina campestris

Petrophile semifur

Bonamia rosea

Conospermum stoechadis

tepidobolus shaetocepha

Mesomelaena preissi

Tetraxia microcarpa

Beyeria cinerea

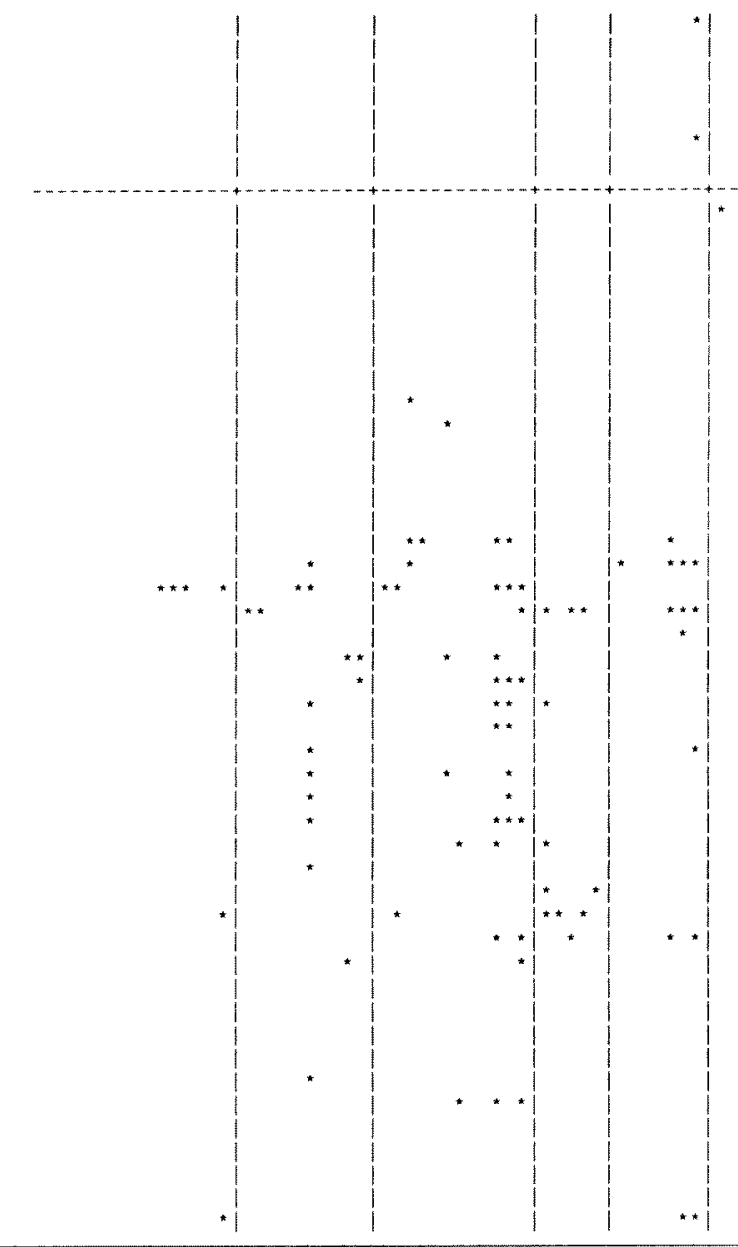




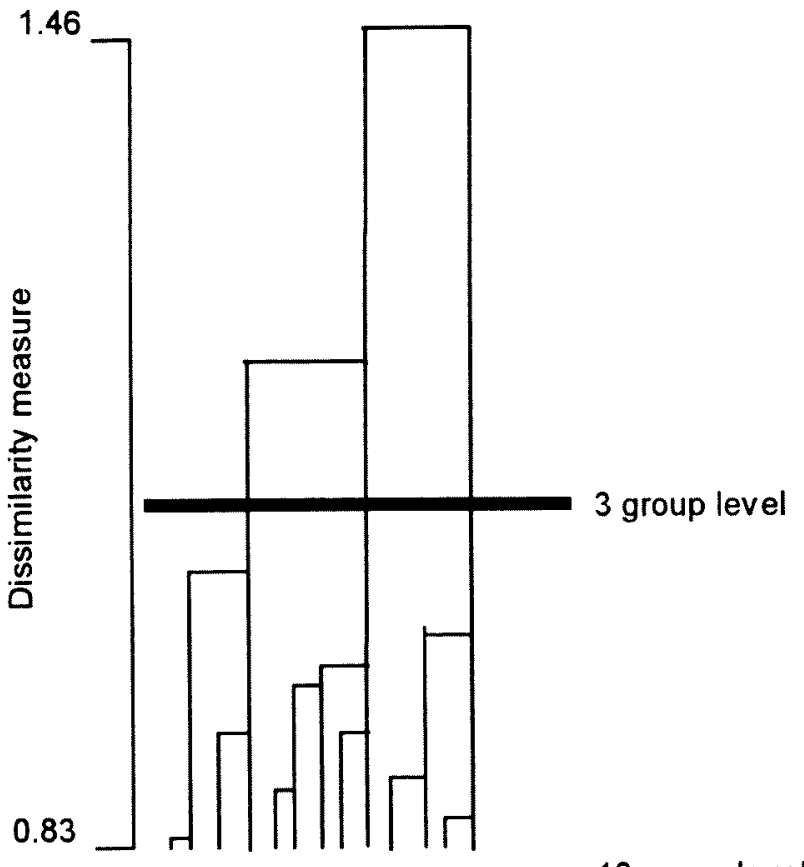

12345678910111213

13 group level

Figure 2 Dendrogram showing the 3 and 13 group classification of the 100 sandplain sites located across the Irwin - Carnarvon boundary.

plot with species assemblages $P$ and $Q$ being typical of this site group. Site group 7 , by contrast, generally consisted of Acacia ligulata and/or Melaleuca cardiophylla shrublands with moderate to high representation of species assemblage $R$, an assemblage almost totally lacking in all other site groups. This assemblage has a high proportion of weeds. Species richness averages 45.5 taxa/plot. Site group 7 is the most widespread group, stretching from the Zuytdorp cliffs through Edel Land and north to Peron Peninsula (Figure 1).

Site group 8 generally consisted of low woodlands of eucalypts or Melaleuca over heath confined to Cooloomia Nature Reserve and areas to the south on red sands generally in swales. Species richness is 34.6 taxa/plot with moderate representation of species assemblage $P$, while species assemblages $Q$ and $R$ are almost totally lacking.
The final major grouping includes the four site groups of the southern coastal area (group III). Site group 10 includes open mallee or Allocasuarina and /or Actinostrobus shrubland over heath on yellow sands. Species richness is relatively low (average of 30.4 taxa/plot). Species assemblage $\mathrm{V}$ is well represented, species assemblage $U$ is less well represented and assemblages $\mathrm{S}$ and $\mathrm{T}$ are totally lacking. This site group geographically overlaps with site groups 2 and 3 . Site group 11 comprises the Actinostrobus - Banksia scrubs and heaths confined to the yellow sands of Kalbarri National Park. High representation of species assemblage $\mathrm{V}$ separates this group from other site groups in the southern coastal area. Average species richness is 43.3 taxa/plot.

Site groups 12 and 13 are the limestone heaths and shrublands of the Zuytdorp and Cooloomia area. Site group 12 occurs on the deeper sands over limestone while site type 13 occurs on skeletal soils over limestone. Species composition is similar with species assemblage $S$ being more typical of the deeper soils and assemblage $T$ of the skeletal soils (Table 1). Average species richness rises from 36.5 taxa/plot on the deeper soils to 43.0 on the thinner soils.

Environmental correlates - Both the 3 and 13 group classifications showed highly significant differences between group means for both climatic and soil parameters. There was also a high degree of correlation between both the climate and soil parameters (Appendix 1). Given this high degree of correlation within the climatic parameters, only patterns in mean annual temperature, mean annual temperature range, mean annual rainfall, and rainfall seasonality are discussed here (Table 2 ).

Group II (the northern coastal site groups) had the highest annual mean temperatures followed by the southern inland group (group I) and then the southern coastal group (group III) which is consistent with their geographical spread (Figure 1). Within the northern coastal group, site group 6 experienced slightly higher temperatures than site group 5 and 9 due to its generally more northern distribution. Site group 7 had a lower mean temperature reflecting its wider geographic spread while site group 8 was much lower than the other

Table 2 Site group averages for mean annual temperature, mean annual temperature range, mean annual rainfall, and rainfall seasonality. (Kruskal-Wallis one way analysis of variance of the 13 site groups showed significant difference between means for all parameters at $P<0.0001$ ).

\begin{tabular}{|c|c|c|c|c|c|c|c|c|c|c|c|c|c|}
\hline \multirow{2}{*}{$\begin{array}{l}\text { Major Group } \\
\text { Site Group }\end{array}$} & \multicolumn{4}{|c|}{ I } & \multicolumn{5}{|c|}{ II } & \multicolumn{4}{|c|}{ III } \\
\hline & 1 & 2 & 3 & 4 & 5 & 6 & 7 & 8 & 9 & 10 & 11 & 12 & 13 \\
\hline Mean temperature $\left({ }^{\circ} \mathrm{C}\right)$ & 21.4 & 20.9 & 20.8 & 21.0 & 21.6 & 21.8 & 21.3 & 21.0 & 21.6 & 20.8 & 20.6 & 20.8 & 20.8 \\
\hline Temperature range $\left({ }^{\circ} \mathrm{C}\right)$ & 28.6 & 28.7 & 28.6 & 28.2 & 27.3 & 26.7 & 26.5 & 27.1 & 27.1 & 28.3 & 27.4 & 27.2 & 27.2 \\
\hline Mean rainfall $(\mathrm{mm})$ & 239 & 267 & 272 & 273 & 247 & 245 & 296 & 302 & 253 & 290 & 355 & 310 & 329 \\
\hline Seasonality & 77.5 & 75.2 & 76.6 & 83.6 & 93.0 & 93.3 & 99.5 & 97.6 & 96.3 & 81.8 & 94.3 & 97.0 & 99.5 \\
\hline
\end{tabular}


site groups reflecting its concentration to the south (Figure 1)

The southern inland group (group I) also showed significant inter site group differences in mean annual temperature (Kruskal-Wallis 31.9, $p<$ 0.0001 ). Site group 1 (the most northern in this group) showed consistent higher temperatures than site groups 2, 3, and 4. Within the southern coastal group (group III), which experienced the lowest annual mean temperatures, site group 11 (on Kalbarri sandplain) was significantly cooler than the more northerly site groups 12 and 13 found in the Zuytdorp Cliff area (Kruskal-Wallis 12.6, $\mathrm{p}<$ 0.01 ).

When annual temperature range is considered, the southern inland group (group I) show a consistent range of about $28-29^{\circ} \mathrm{C}$. The northern coastal group (group II) has a significantly lower temperature range, especially those sites on Peron Peninsula and Edel Land, where the annual temperature range drops to $26-27^{\circ} \mathrm{C}$. Site groups 5 , 8 and 9 have similar ranges. Within the southern coastal group (group III) the inland site group (site group 10) has a greater annual temperature range than the other three site groups.

Mean annual rainfall and rainfall seasonality both showed highly significant between group differences both at the 3 group and 13 group classifications. Rainfall generally decreases away from the coast across the study area and is somewhat higher in the south than the north (Beard 1976a). The southern coastal group (group III) has the highest annual rainfall and within this group, site group 11 (the Kalbarri sandplain sites) is higher than the remaining site groups. Site group 10 (the most inland of this group) has the lowest annual rainfall. Site groups 3 and 4 (belonging to the southern inland grouping (group I)) occur further inland still and show further decreases in rainfall. The lowest mean annual rainfall $(240-245 \mathrm{~mm})$ are found in site groups 1,5 and 6 , consistent with the above pattern (Figure 1).

The most strongly seasonal patterns in rainfall are seen in the high rainfall southern coastal group (group III) and the northern coastal grouping (group II) (Table 2). The more inland site groups had a less predictable climate and hence less pronounced seasonality. This trend is apparent within the southern coastal group where the most inland of site groups (10) has a significantly less seasonal rainfall pattern than site groups 11, 12 and 13 (Table 2, Kruskal-Wallis 19.1, $p<0.001$ ).

Soil nutrient and mechanical parameters also showed highly significant differences between group means for both the 3 group and 13 group classifications and within the three major groups (Tables 3 and 4). The most striking differences are the high $\mathrm{pH}$, high electrical conductivity, and high nutrient levels of the northern coastal group (group II) with considerable variability of parameters within its 5 site groups.

The southern inland (group I) and southern coastal (group III) groups are acidic sands with the inland group having generally lower $\mathrm{pH}$ than the coastal group (Table 3). The yellow sands of the southern coastal group (group III) showed less variability in $\mathrm{pH}$ than the southern inland group (group I). Within the southern coastal group, site group 10 (inland sites) has a significantly lower $\mathrm{pH}$ than site group 13 (coastal scrubs) (Kruskal-Wallis

Table 3 Means values for the 13 site groups for soil parameters. Sig. Diff. indicates significant differences between means of the 13 groups based on Kruskal - Wallis one way analysis of variance $\left(^{* * *}=p<0.001,{ }^{* * * *}=p<\right.$ $0.0001)$.

\begin{tabular}{|c|c|c|c|c|c|c|c|c|c|c|c|c|c|c|}
\hline \multicolumn{2}{|c|}{ Major Group } & \multicolumn{3}{|c|}{ I } & \multicolumn{5}{|c|}{ II } & \multicolumn{4}{|c|}{ III } & \multirow{2}{*}{$\begin{array}{l}\text { Sig. } \\
\text { Diff. }\end{array}$} \\
\hline Site Group & 1 & 2 & 3 & 4 & 5 & 6 & 7 & 8 & 9 & 10 & 11 & 12 & 13 & \\
\hline $\mathrm{EC}$ & 1.64 & 1.60 & 1.08 & 1.00 & 5.29 & 5.56 & 12.75 & 5.00 & 8.00 & 1.09 & 2.17 & 3.00 & 2.00 & $* * * *$ \\
\hline $\mathrm{pH}\left(\mathrm{H}_{2} \mathrm{O}\right)$ & 5.8 & 6.5 & 5.9 & 6.1 & 8.0 & 7.6 & 8.9 & 7.2 & 8.5 & 6.2 & 6.5 & 6.5 & 6.7 & $* * * *$ \\
\hline $\mathrm{C}$ & 0.37 & 0.41 & 0.41 & 0.37 & 0.33 & 0.31 & 0.96 & 0.46 & 0.41 & 0.30 & 0.35 & 0.39 & 0.46 & $* * *$ \\
\hline Total N & 0.02 & 0.03 & 0.02 & 0.02 & 0.02 & 0.03 & 0.08 & 0.03 & 0.02 & 0.01 & 0.01 & 0.02 & 0.02 & $* * * *$ \\
\hline Total P & 70.8 & 61.2 & 36.1 & 32.3 & 41.4 & 61.6 & 298.5 & 53.0 & 35.3 & 27.5 & 17.7 & 22.3 & 39.0 & $* * * *$ \\
\hline Avail $P$ & 3.21 & 3.80 & 1.54 & 1.50 & 3.43 & 5.44 & 12.13 & 4.80 & 2.00 & 0.91 & 0.50 & 0.75 & 1.25 & $* * * *$ \\
\hline Avail K & 36.9 & 101.4 & 23.3 & 21.3 & 40.1 & 115.8 & 75.6 & 41.8 & 29.0 & 18.2 & 16.2 & 18.3 & 26.3 & $* * * *$ \\
\hline Exch Ca & 0.52 & 1.35 & 0.52 & 0.58 & 1.67 & 2.25 & 4.03 & 2.56 & 2.14 & 0.46 & 0.94 & 1.01 & 1.15 & $* * * *$ \\
\hline Exch $\mathrm{Mg}$ & 0.13 & 0.51 & 0.13 & 0.17 & 0.27 & 0.53 & 0.57 & 0.27 & 0.26 & 0.13 & 0.19 & 0.23 & 0.28 & $* * * *$ \\
\hline Exch K & 0.06 & 0.17 & 0.04 & 0.04 & 0.06 & 0.18 & 0.20 & 0.05 & 0.04 & 0.03 & 0.02 & 0.02 & 0.05 & $* * * *$ \\
\hline Exch $\mathrm{Na}$ & 0.02 & 0.05 & 0.00 & 0.00 & 0.03 & 0.06 & 0.15 & 0.03 & 0.04 & 0.00 & 0.01 & 0.04 & 0.03 & $* * * *$ \\
\hline Sand & 91.4 & 89.9 & 92.2 & 92.8 & 95.3 & 93.8 & 91.2 & 96.0 & 95.7 & 92.8 & 95.8 & 96.9 & 95.0 & $* * * *$ \\
\hline Silt & 1.4 & 2.3 & 1.5 & 1.7 & 1.1 & 1.5 & 2.6 & 0.8 & 0.5 & 1.6 & 1.6 & 0.8 & 0.9 & $* * * *$ \\
\hline Clay & 7.3 & 7.9 & 6.3 & 5.5 & 3.6 & 4.7 & 6.0 & 3.2 & 3.8 & 5.6 & 2.7 & 2.4 & 4.3 & $* * * *$ \\
\hline $\begin{array}{l}\text { No of } \\
\text { quadrats }\end{array}$ & 16 & 10 & 12 & 5 & 7 & 9 & 8 & 5 & 3 & 11 & 6 & 4 & 4 & \\
\hline
\end{tabular}


$8.6, p<0.05)$. The sandy soils of the northern coastal group are significantly more alkaline than either of the other major groups (Kruskal-Wallis 63.8, $\mathrm{p}<$ $0.0001)$. The most alkaline site group (7, mean $\mathrm{pH}$ 8.9) occurs on coastal dunes from Peron Peninsula to Zuytdorp Cliffs while site groups 5 and 9 of the red sandplain south of Shark Bay recorded average $\mathrm{pH}$ of $8-8.5$. The mean $\mathrm{pH}$ of the remaining site groups of this northern coastal grouping ranges from $7.2-7.6$.

Electrical conductivity showed an even more pronounced differentiation of the northern coastal group (group II) from the remaining groups (Table 3). Again site groups 7 and 9 recorded the highest electrical conductivity values within this group. Similar patterns are seen for available $P, K$, exchangeable $\mathrm{Ca}, \mathrm{K}, \mathrm{Mg}$ and $\mathrm{Na}$ (Table 3). Four quadrats in site group 2 show consistent elevated values for $\mathrm{K}$ and exchangeable $\mathrm{Mg}, \mathrm{Ca}$ and $\mathrm{K}$ that are not clearly apparent in the electrical conductivity data. Site groups 12 and 13 show higher exchangeable $\mathrm{Ca}$ and $\mathrm{Na}$ and electrical conductivity values than are apparent for other site groups in the southern coastal grouping (group III) (Table 3).

The pattern for $\mathrm{C}, \mathrm{N}$ and total $\mathrm{P}$ differ from the patterns described above with a strong peak only in community type 7 (Table 3 ). Both total and available $\mathrm{P}$ show elevated levels in the southern inland group (group I) compared with the southern coastal group (group III) (Table 3). Within the southern inland group there are significantly different mean values of total and available $P$ (Kruskal-Wallis 24.3 and 16.5 respectively, $\mathrm{P}<$ 0.001 ) with site groups 1 and 2 showing about twice

Table 4 Significance differences between site group means within the southern inland group (group I), the northern coastal group (group II) and the southern coastal group (group III) based on Kruskal - Wallis one way analysis of variance. $\left({ }^{*}=p<0.05,{ }^{* *}=p<0.01,{ }^{* * *}=p<\right.$ $\left.0.001,{ }^{* * * *}=\mathrm{p}<0.0001\right)$.

\begin{tabular}{llll}
\hline & Group I & Group II & Group III \\
\hline EC & ns & $* *$ & $*$ \\
pH $(\mathrm{H} 20)$ & $*$ & $* * *$ & $*$ \\
C & $n s$ & $* *$ & $* *$ \\
Total N & $n s$ & $* *$ & $*$ \\
Total P & $* * * *$ & $* * *$ & $* *$ \\
Avail P & $* * *$ & $* *$ & $*$ \\
Avail K & $* * *$ & $* * *$ & $n s$ \\
Exch Ca & $*$ & $* *$ & $* * *$ \\
Exch Mg & $* *$ & $* *$ & $* *$ \\
Exch K & $* * *$ & $* * *$ & $n s$ \\
Exch Na & $*$ & $* *$ & $* *$ \\
Sand & $*$ & & $* *$ \\
Silt & ns & $* *$ & $* *$ \\
Clay & $*$ & $*$ & $* *$ \\
\hline
\end{tabular}

the values of site groups 3 and 4 (Table 3 ). Significant differences were also found between the means of total and available $P$ of site groups in group II and in group III (Table 4).

Mechanical analysis showed similar patterning to that seen in the soil chemistry data (Table 3). All sites were on either sands or sandy loams with the southern inland group (group I) having the highest clay contents. Within this group, site group 4 had low average clay content $(5.5 \%)$ while site groups 1 and 2 had clay contents of $7.3 \%$ and $7.9 \%$ respectively. The northern coastal group also exhibited significant differences in clay content between site groups with the highest levels found in site group 7 (average of $6 \%$ clay) and the other site group means ranging from 3.2 to $4.7 \%$ (KruskalWallis $11.3, \mathrm{p}<0.05)$. Site 70 , which is an outlying site in site group 6, had much higher average clay content than other sites in this group. The level of clay at this site is similar to those of site group 1 that occur in the immediate vicinity (Table 3, Figure 1).

The southern coastal group (group III) generally showed the lowest average soil clay content. Within this group highly significant variation was seen between site groups (Table 3 and 4), with site groups 11 and 12 showing the lowest average clay content $(2.4-2.7 \%)$ while site groups 10 and 13 had average clay contents of 4.3 to $5.6 \%$. Percentage clay content was highly correlated with soil nutrient levels, and percentage silt showed a degree of weak correlation with some soil nutrient parameters (Appendix 1).

\section{DISCUSSION}

Beard's (1980) classification of phytogeographic regions attempts to identify natural ecological regions "each of which possesses its own characteristic landscape due to its particular features of climate, geology, landforms, soils and vegetation". He used vegetation (mapped in terms of structure, density and composition of the dominant taxa) as the indicator of these regions. The phytogeographic boundary between the Irwin and Carnarvon botanical districts also represents the boundary between two of the major floristic provinces (temperate Southwestern and arid Eremaean) in Western Australia.

Our analysis of floristic patterning of comprehensive lists from 100 sites across this boundary sought to test the current placement of this major phytogeographic boundary independently of Beard's vegetation units. One possible drawback of this approach is that seasonality in annual and geophyte occurrence could influence the floristic classification. However, while no detailed studies on seasonality have been undertaken in this region (low rainfall temperate), 
Table 5 Comparison of the 3 group and 13 group floristic classifications with Beard's phytogeographic districts and vegetation systems. Figures in the table are the number of quadrats.

\begin{tabular}{|c|c|c|c|c|c|c|c|c|c|c|c|c|c|c|}
\hline \multirow[b]{2}{*}{ District } & \multirow[b]{2}{*}{ Vegetation system } & \multicolumn{4}{|c|}{ I } & \multicolumn{5}{|c|}{ II } & \multicolumn{4}{|c|}{ III } \\
\hline & & 1 & 2 & 3 & 4 & 5 & 6 & 7 & 8 & 9 & 10 & 11 & 12 & 13 \\
\hline \multicolumn{15}{|c|}{ Carnarvon } \\
\hline & Lharidon & & & & & & 6 & & & & & & & \\
\hline & Denham & & & & & & & 2 & & & & & & \\
\hline & Peron & & & & & & & 1 & & & & & & \\
\hline & Carrarang & & & & & & & 2 & & & & & & \\
\hline & Talisker & 7 & 6 & 3 & & & & & & & & & & \\
\hline & not mapped & 6 & & & & 3 & 1 & & & & & & & \\
\hline \multicolumn{15}{|l|}{ Irwin } \\
\hline & Tamala & & & & & 4 & 2 & & 3 & 3 & & & & \\
\hline & Zuytdorp & & & & & & & 3 & 2 & & & & & 4 \\
\hline & Eurardy & 3 & & 2 & 4 & & & & & & 4 & 1 & 4 & \\
\hline & Yuna & & 4 & 7 & 1 & & & & & & 7 & & & \\
\hline & Kalbarri & & & & & & & & & & & 5 & & \\
\hline
\end{tabular}

all sites were visited at least once following good winter rains and, with the exception of site groups 5 and 9, the classification shows no segregation by year of sampling, implying that the influence of any seasonal component in the data analysis is low.

Our data show very strong correlation of edaphic and climatic factors with floristic composition at both the 3 and 13 group levels, but generally poor correlation with Beard's phytogeographic districts and vegetation systems (Table 5). Our southern coastal group (group III) was however entirely confined to Beard's Irwin district and within this group there was good correlation between three of the four site groups and Beard's vegetation systems (Table 5).

This southern coastal group (group III) can clearly be considered a southwestern group in terms of family and species composition (Tables 1 and 6). It is the outlying group in our classification (Figure 2) with groups I and II being floristically more similar and having more overall similarities with the Eremaean region (Tables 1 and 6). These results are at variance with the present location of the Irwin Carnarvon boundary and suggest that the southern section of this boundary should be placed $25 \mathrm{~km}$ further to the west then swing to the coast in the

Table 6 Comparison of patterns in composition of the most common families between plots in the tree heath (site groups 5 and 9) with those typical of the Irwin (site groups 10 to 13) and the Carnarvon (site group 1). Percentage composition calculated for taxa recorded within each group and mean species richness $/ 100 \mathrm{~m}^{2}$.

\begin{tabular}{lccc}
\hline & $\begin{array}{c}\text { Irwin plots } \\
\text { (site groups }\end{array}$ & $\begin{array}{c}\text { Tree heath plots } \\
\text { (site group 5 and 9) }\end{array}$ & $\begin{array}{c}\text { Carnarvon plots } \\
\text { (site group 1) }\end{array}$ \\
\hline No of plots & 25 & 10 & 16 \\
Total number of species & 309 & 166 & 173 \\
Total number of families & 50 & 46 & 48 \\
Mean species richness & 40.0 & 38.3 & 40.0 \\
Myrtaceae & 23.3 & 15.1 & 6.4 \\
Proteaceae & 11.3 & 6.0 & 5.2 \\
Mimosaceae & 6.1 & 8.4 & 5.7 \\
Papilionaceae & 6.1 & 1.8 & - \\
Cyperaceae & 4.5 & - & - \\
Haemodoraceae & 3.2 & - & 23.7 \\
Asteraceae & 2.9 & 10.8 & - \\
Dilleniaceae & 2.6 & 1.2 & 4.6 \\
Goodeniaceae & 2.6 & 1.2 & 4.6 \\
Poaceae & 2.6 & 5.4 & 1.7 \\
Chloanthaceae & 1.9 & 4.2 & 2.9 \\
Apiaceae & 1.3 & 0.6 & 4.0 \\
Amaranthaceae & 0.6 & 2.4 & 1.2 \\
Chenopodiaceae & 0.3 & 3.7 & 4.0 \\
Myoporaceae & 0.3 & 3.0 & 4.0 \\
Solanaceae & 0.3 & 3.0 & \\
\hline
\end{tabular}




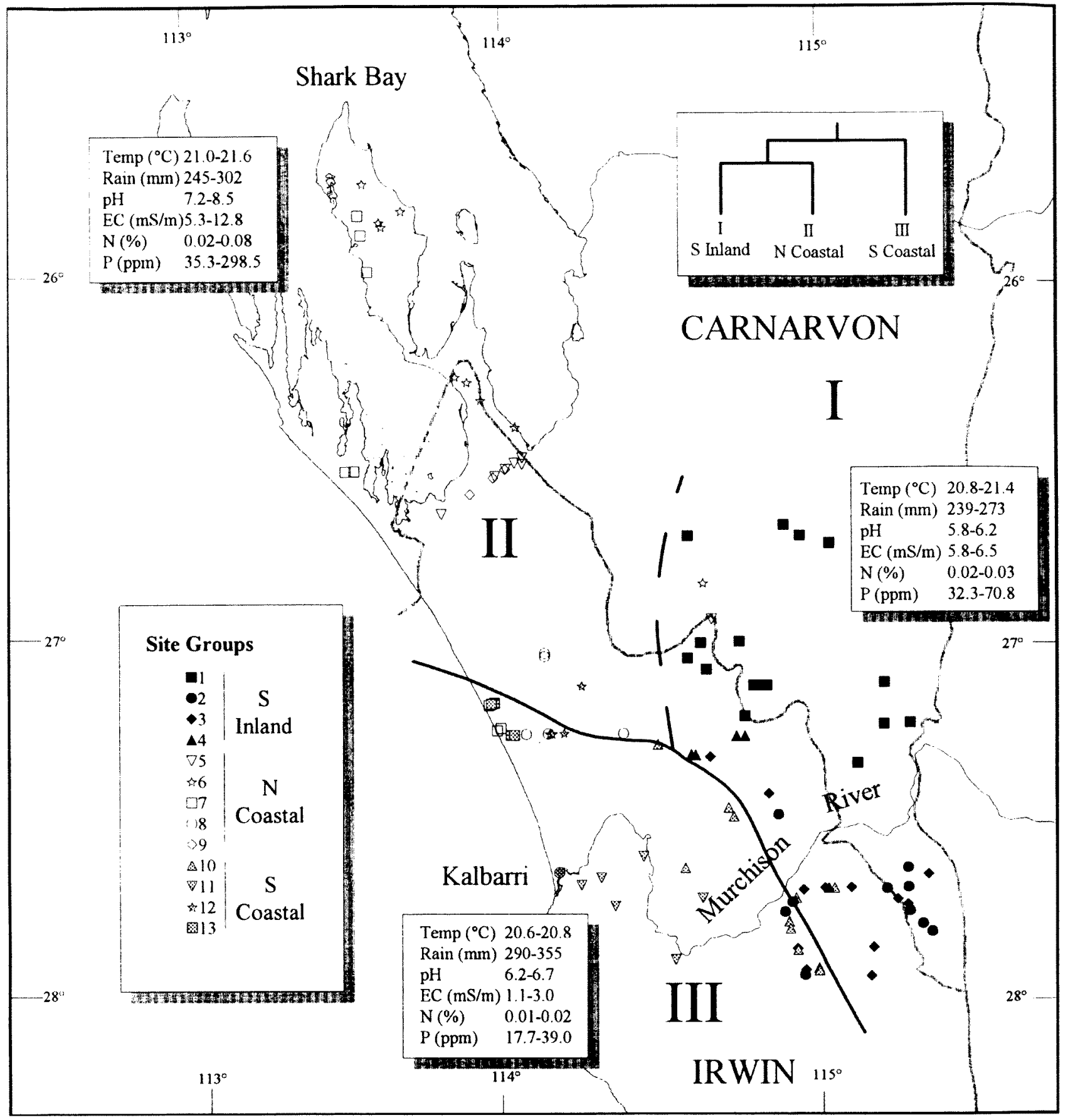

Figure 3 Present location of the phytogeographic boundaries (solid grey lines), proposed position of the Irwin Carnarvon boundary (solid black line), and separation between southern inland (group I) and northern coastal (group II) floristic groups (dashed black line). For each of the three major groups the range in site group means for temperature, rainfall, $\mathrm{pH}$, electrical conductivity and total $\mathrm{P}$ and total $\mathrm{N}$ shown in boxes.

vicinity of the Zuytdorp cliffs south of the tree heath to more fully conform with patterns in species composition (Figure 3).

The present position of the southern section of the Irwin - Carnarvon boundary separates the Acacia - Casuarina thicket on red sandplain (Irwin) from the Acacia ramulosa/linophylla scrub with scattered pines and eucalypts (Carnarvon) (Beard, 1976a, 1976b, 1976c). Moving this boundary $25 \mathrm{~km}$ to the west would include the Acacia - Casuarina thicket in the Carnarvon district and result in the Irwin boundary being defined by Beard's scrub heaths on yellow sandplain. Our analysis then suggests that the Irwin boundary should then follow the southern boundary of the tree heaths to the coast.

All previous workers, except Clarke (1926), have placed these tree heaths in the Irwin district, however when patterns in species and family composition of sites in this unit (site 
groups 5 and 9) are compared with site groups 10 to 13 (all within the Beard's Irwin district) and site group 1 (predominantly in Beard's Carnarvon district) it is clear that tree heaths are more similar in terms of total species composition (cf. dominants) to typical Eremaean pattern than that of the Southwest. There is no difference in mean species richness between these groups (Table 6).

Our soil chemical data lend no support to the current placement of the Irwin - Carnarvon boundary (Table 3, Figure 3) The predominantly red sand sheets occupied by sites in our southern inland group (group I) show almost total segregation in terms of $\mathrm{pH}$, electrical conductivity, and total $\mathrm{N}$ and total $\mathrm{P}$ and clay content for site group means from the other groups (Figure 3, Table 3). Similarly our northern coastal group (group II) has more calcareous sands of higher P content than either groups I or III, suggesting these three sand sheets have different origins. More detailed analysis of the soil profiles would be needed to confirm this.

The shallow nature of climatic gradients is a feature of this part of Western Australia, where the whole of the study area is in a predominantly winter rainfall zone, with total mean annual precipitation decreasing to the north and east. Climate estimates for our sites are consistent with this pattern with the highest rainfall and a high seasonality seen in the southern coastal group (group III) (Table 2, Figure 3). Rainfall maps in Beard (1976a) suggest the $300 \mathrm{~mm}$ isohyet extends up the Edel Land Peninsular and bisects Dirk Hartog Island, although more recent data (Anonymous, 1986) indicate that this isohyet cuts the coast just north of Kalbarri. This isohyet has long been regarded as significant in delimiting the Southwestern and Eremaean Provinces, disregarding its incorrect map position (Diels, 1906; Gardner and Bennetts, 1956; Beard, 1976a).

The placement of the Carnarvon - Irwin boundary $25 \mathrm{~km}$ to the west and swinging south of the tree heath on red sandplain (Figure 3 ) would make it consistent with strongly correlated patterns demonstrated between the species composition analysis and the edaphic and climatic parameters of our sites, and more closely fit Beard's (1980) concept of natural ecological regions. Our data strongly suggest Beard's interpretation of the vegetation of the peninsulas and islands of the Shark Bay area in the Carnarvon botanical district is correct (cf. Burbidge and George, 1978; Thackway and Cresswell, 1995) however our analysis suggests that the tree heaths and Acacia shrublands on the red sandplains east of Kalbarri should also be regarded as part of the Carnarvon botanical district.

\section{ACKNOWLEDGEMENTS}

Two referees are thanked for detailed comments on an earlier draft of this paper.

Funding was provided by the Commonwealth through the National Reserves System Co-operative Program of the Australian Nature Conservation Agency (now Environment Australia), and by the Western Australian Department of Conservation and Land Management.

\section{REFERENCES}

Anonymous (1986). Atlas of Australian Resources. Third series, Volume 4, Climate. Division of National Mapping, Canberra.

Austin, M.P. and Belbin, L. (1982). A new approach to the species classification problems in floristic analysis. Australian Journal of Ecology 7: 75-89.

Beard, J.S. (1975). Vegetation survey of Western Australia Pilbara 1:1000000 vegetation series. University of Western Australia Press, Perth.

Beard, J.S. (1976a). Vegetation survey of Western Australia Murchison 1: 1000000 vegetation series. University of Western Australia Press, Perth

Beard, J.S. (1976b). The vegetation of the Shark Bay and Edel area, Western Australia - 1:250 000. Vegmap Publications, Perth.

Beard, J.S. (1976c). The vegetation of the Ajana area, Western Australia - 1:250 000. Vegmap Publications, Perth.

Beard, J.S. (1980). A new phytogeographic map for Western Australia. Western Australian Herbarium Research Notes 3: 37-58.

Beard, J.S. (1990). Plant Life of Western Australia. Kangaroo Press, Kenthurst.

Burbidge, A.A. and George, A.S. (1978). The flora and fauna of Dirk Hartog Island, Western Australia. Journal of the Royal Society of Western Australia 60: 7190.

Burbidge, N.T. (1960). The phytogeography of the Australian region. Australian Journal of Botany 8: 75 211

Clarke, E. (1926). Natural regions in Western Australia Journal of the Royal Society of Western Australia 12: 117132

Diels, L. (1906). Die Pflanzenwelt von West-Australien sudlich des Wendekreisses. Vegetation der Erde 7 Leipzig.

Gardner, C.A. (1944). The vegetation of Western Australia with special reference to the climate and soils. Journal of the Royal Society of Western Australia 28: $11-87$.

Gardner, C.A. and Bennetts, H.W. (1956). The Toxic Plants of Western Australia. WA Newspapers, Perth.

Green, J.W. (1985). Census of the Vascular Plants of Western Australia. Department of Agriculture, Perth.

Keighery, G.J., Gibson, N., Lyons, M.N. and Burbidge, A.H. (2000). Flora and vegetation of the southern Carnarvon Basin, Western Australia. Records of the Westem Australian Museum Supplement No. 61: 77154. 
McArthur, W.M. (1991). Reference Soils of South-western Australia. Department of Agriculture, Perth.

Siegel, S. (1956). Non-Parametric Statistics for Behavioral Sciences. McGraw-Hill, New York.

Sneath, P.H.A. and Sokal, R.R. (1973). Numerical Taxonomy: The Principles and Practice of Numerical Classification. Freeman, San Francisco.

Thackway, R. and Cresswell, I.D. (eds) (1995). An Interim Biogeographical Regionalisation for Australia: a Framework for Establishing the National System of
Reserves, Version 4.0. Australian Nature Conservation Agency, Canberra.

Wyrwoll, K.-H., Stoneman, T., Elliott, G. and Sandercock, P. (2000). Geoecological setting of the Carnarvon Basin, Western Australia: geology, geomorphology and soils of selected sites. Records of the Western Australian Museum Supplement No. 61: 29-75.

Manuscript received 26 May 1998; accepted 14 April 2000. 


\section{APPENDIX 1}

Matrix of Spearman Rank Correlation coefficients for climatic and soil parameters. Correlations in bold are significant at $p<0.01$.

\begin{tabular}{|c|c|c|c|c|c|}
\hline & Ca Exch & Clay & $C$ & $\mathrm{EC}$ & K Exch \\
\hline $\mathrm{Ca}$ Exch & 1.000 & & & & \\
\hline Clay & -0.146 & 1.000 & & & \\
\hline $\mathrm{C}$ & 0.488 & 0.194 & 1.000 & & \\
\hline $\mathrm{EC}$ & 0.818 & -0.174 & 0.376 & 1.000 & \\
\hline K Exch & 0.553 & 0.424 & 0.285 & 0.535 & 1.000 \\
\hline K & 0.661 & 0.298 & 0.311 & 0.614 & 0.867 \\
\hline Mg Exch & 0.921 & -0.110 & 0.429 & 0.754 & 0.614 \\
\hline $\mathrm{Na}$ Exch & 0.756 & -0.023 & 0.419 & 0.758 & 0.566 \\
\hline Total N & 0.714 & 0.295 & 0.770 & 0.624 & 0.670 \\
\hline Rainfall & 0.125 & -0.258 & 0.260 & -0.029 & -0.250 \\
\hline P Available & 0.614 & 0.336 & 0.288 & 0.621 & 0.731 \\
\hline $\mathrm{pH}$ & 0.904 & -0.285 & 0.265 & 0.785 & 0.441 \\
\hline Seasonality & 0.634 & -0.559 & 0.271 & 0.642 & 0.154 \\
\hline Total P & 0.415 & 0.588 & 0.417 & 0.432 & 0.756 \\
\hline Sand & 0.322 & -0.745 & 0.004 & 0.374 & -0.204 \\
\hline Silt & 0.161 & 0.584 & 0.281 & 0.047 & 0.334 \\
\hline Annual Temp & 0.219 & -0.024 & -0.127 & 0.407 & 0.407 \\
\hline \multirow[t]{2}{*}{ Temp Range } & -0.654 & 0.533 & -0.233 & -0.638 & -0.205 \\
\hline & K & Mg Exch & Na Exch & Total N & Rainfall \\
\hline K & 1.000 & & & & \\
\hline Mg Exch & 0.691 & 1.000 & & & \\
\hline Na Exch & 0.602 & 0.752 & 1.000 & & \\
\hline Total N & 0.756 & 0.660 & 0.626 & 1.000 & \\
\hline Rainfall & -0.351 & 0.133 & -0.010 & -0.067 & 1.000 \\
\hline P Available & 0.839 & 0.556 & 0.576 & 0.725 & -0.412 \\
\hline $\mathrm{pH}$ & 0.517 & 0.822 & 0.673 & 0.481 & 0.151 \\
\hline Seasonality & 0.155 & 0.588 & 0.533 & 0.281 & 0.442 \\
\hline Total P & 0.770 & 0.384 & 0.506 & 0.749 & -0.383 \\
\hline Sand & -0.070 & 0.287 & 0.248 & -0.092 & 0.251 \\
\hline Silt & 0.278 & 0.178 & 0.051 & 0.339 & 0.132 \\
\hline Annual Temp & 0.486 & 0.191 & 0.332 & 0.260 & -0.805 \\
\hline \multirow[t]{2}{*}{ Temp Range } & -0.192 & -0.616 & -0.529 & -0.269 & -0.453 \\
\hline & P Available & $\mathrm{pH}$ & Seasonality & Total P & Sand \\
\hline P Available & 1.000 & & & & \\
\hline $\mathrm{pH}$ & 0.500 & 1.000 & & & \\
\hline Seasonality & 0.102 & 0.696 & 1.000 & & \\
\hline Total P & 0.843 & 0.247 & -0.022 & 1.000 & \\
\hline Sand & -0.119 & 0.457 & 0.584 & -0.350 & 1.000 \\
\hline Silt & 0.281 & 0.074 & -0.173 & 0.325 & -0.482 \\
\hline Annual Temp & 0.551 & 0.227 & 0.099 & 0.441 & 0.011 \\
\hline \multirow[t]{2}{*}{ Temp Range } & -0.126 & -0.747 & -0.943 & 0.047 & -0.596 \\
\hline & Silt & Annual Temp. & Temp. Range & & \\
\hline Silt & 1.000 & & & & \\
\hline Annual Temp & -0.231 & 1.000 & & & \\
\hline Temp Range & 0.113 & -0.075 & 1.000 & & \\
\hline
\end{tabular}

